\title{
Strategies for assessment and implementation of sustainable manufacturing
}

\author{
Deepak Sharma \\ Department of Mechanical Engineering, Delhi Technological University, Delhi, India. \\ Department of Mechanical Engineering, GLA University, Mathura, India \\ Corresponding Author : deep241087@gmail.com
}

\begin{abstract}
Manufacturing has been acknowledged for the intensive use of renewable raw materials, energy sources, and a significant contributor to pollutants causing multiple environmental issues and health hazards to the community. Sustainable manufacturing is a necessary prerequisite to conserve natural resources, mitigate the adverse impacts on environment, global economy, and society. It is important to identify and understand the implementation steps and the evaluation process for developing a sustainable manufacturing system. In this review, sustainable manufacturing has been described for better understanding of the concept. The insights about existing sustainability metrics with the inclusion of environmental, economic and social aspects of sustainability has been explored. The various sustainability indicators have been documented to provide an overview for sustainability assessment framework. In addition, the gaps in the existing sustainability metrics have been identified and the future goals for tailoring the current indicators has been explored. Thus, the study provides strategies for suitable sustainability assessment and action-plan for implementation of sustainable manufacturing.
\end{abstract}

Key words: Manufacturing; Sustainability; Environment; Economy; Society.

\section{INTRODUCTION}

The rapid increasing deforestation and the use of natural resources have given rise to significant environmental issues that have led to the need for sustainability that is fulfilling the needs of the current without jeopardizing the capacity of future generations to fulfil their own needs (Lami \& Mecca, 2021). In addition, intensive industrialization has resulted in various social, financial, and environmental issues due to ineffective utilization of capital resources. The critical social issues involve health, safety, and quality of life whereas financial issues involve production cost, unemployment and business opportunities for human beings (Beng \& Omar, 2014). The environmental issues related to the global warming, availability of pollution free environment and maintenance of ecological balance are of prime concern. The concept of sustainability is based upon addressing these issues by innovative and smart approach (Jung et al., 2018).

In the current era, manufacturing is a source of goods and resources essential for all day-to-day activities involving living, health, and safety of human beings and significantly impact the global economy (Ahmad et al., 2018). However, manufacturing is not limited to only the production process but is a chain of various processes right from the production using raw material and ends at consumption and disposal process. While production processes aid to financial gain, the consumption of a lot of resources with the production of waste is a matter of concern (Ahmad et al., 2019). The waste produced, during the processing process, during the product use, and after the end of the product life, is responsible for environmental degradation (Pinto et al., 2020). Thus, it becomes increasingly important to 
mitigate the resource use and reduce the environmental effects of production processes (Pereira et al., 2019). Hence, a sustainability approach is necessary for long-run manufacturing operations in the context of the environment and economic perspective. (Akbar \& Irohara, 2018).

The concept of "sustainable manufacturing" applies to all operations in the manufacturing units including all intermediate measures related to manufacturing resources and services (Sudusinghe \& Seuring, 2020). Literature reports that consumers can afford to invest additional funds if better products are offered by the production units (Zhou et al., 2016). Thus, sustainable production can be an important approach for fostering improved financial results in addition to achieving social and environmental goals as illustrated in Figure 1. Consequently, industries must aim for sustainable manufacturing on their side. The sustainable use of natural resources and energy efficient processes can not only deliver desired services with improved products but can also ensure the health and safety of all participants (Murakami et al., 2020). Therefore, there is an emerging need for a global initiative to practice sustainability in various industries and organizations (Jawahir et al., 2015).

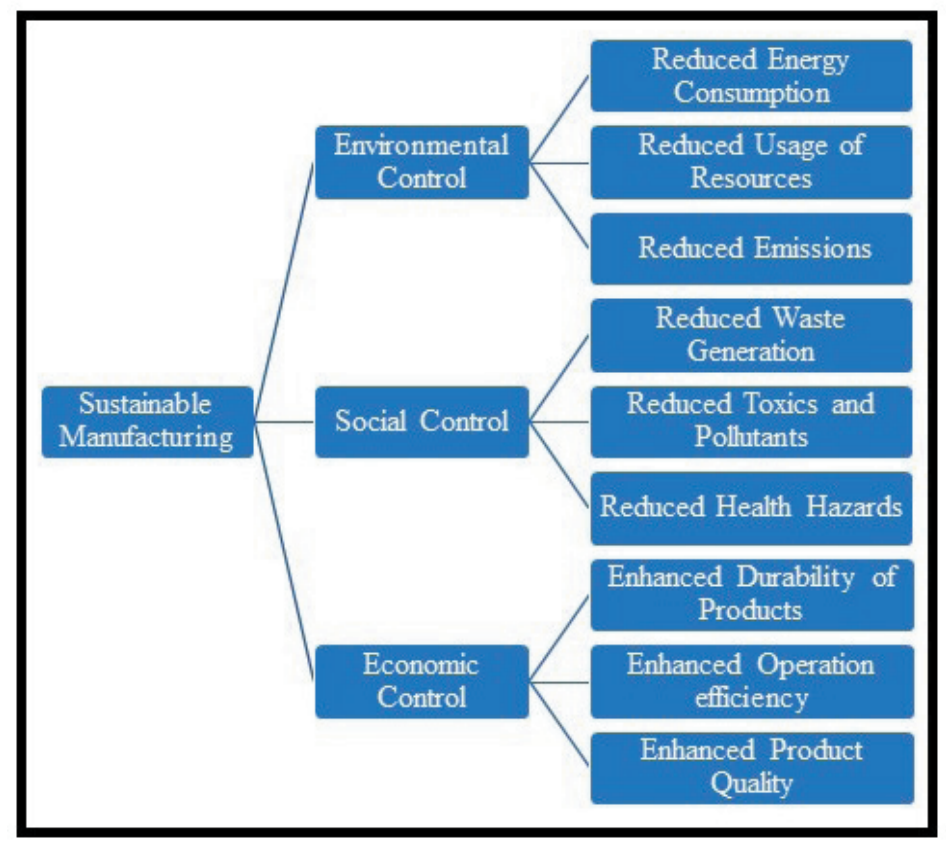

Figure 1. Concept of Sustainable Manufacturing

However, the global conceptualization and integration of sustainable manufacturing still require bridging the theoretical and practical approaches with resolution of the incurring financial, social and environmental issues (Abualfaraa et al., 2020). In this regard, sustainability metrics including the suitable indicators is highly desirable to access the sustainable manufacturing approach used by the industrial units. Literature reports that the sustainability metrics developed by various organizations are varied but connect to the ultimate goal of sustainability (Ahmad et al., 2019). For example, the Organization for Economic Cooperation and Development (OECD) specified 50 core environmental indicators to assess environmental effects of industrial practices in developed countries, while the UN Commission on Sustainable Development defined 92 indicators to address environmental degradation due to human activities (Rosen \& Kishawy, 2012).

This paper is a comprehensive study aimed to provide a conceptual framework in terms of sustainable prospective for social, economic, and environmental management. The sustainability indicators including environmental, social 
and economic indicators as per existing literature have been explored in section 2 . The future goals for sustainability assessment in order to fill the gaps in existing framework have been explored in the subsequent section with concluding remarks.

\section{SUSTAINABILITY INDICATORS}

There has been an increasing pressure of environmental and social impact on manufacturing in addition to economic gains. Hence, manufacturers are looking forward to encouraging production practices that preserve the economic benefits with minimal environmental and social effects (Huang \& Badurdeen, 2017). Also, with growing customer and employee awareness, desire for sustainable culture has led the global industries to adopt sustainable manufacturing strategies in the current competitive economic environment (Garza-Reyes, 2015).

Literature reports few appropriate assessment tools based upon some metrics for assessing sustainability and determining the environmental and social impacts of production (Ahmad et al., 2019; Wu \& Su, 2020). However, there is no uniformity on taxonomy of sustainability metrics and industrial units need to consider appropriate measures and indicators for achieving the goals of sustainable processes and products (Chaim et al., 2018). In general, the list of indicators prescribed by various systems is very exhaustive and it is very difficult to define and use comprehensive, standardized, and usable indicators for a sustainable manufacturing procedure (Singh et al., 2007). Therefore, defining, categorizing, and summarizing an exhaustive collection of indicators and assessment techniques is highly desirable for modeling sustainability issues (Bui et al., 2017). A thorough study of the literature reveals that the sustainability aspects of manufacturing systems (Figure 2) are mainly assessed by three main indicators as discussed ahead.

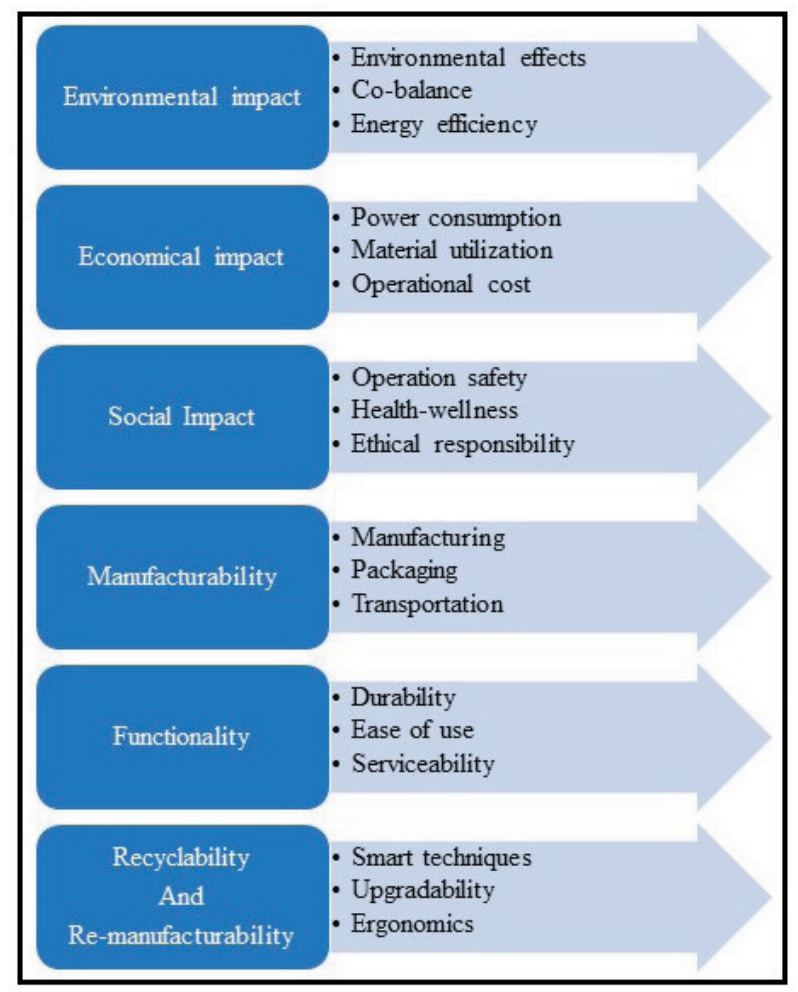

Figure 2. Key Factors for consideration in sustainable manufacturing 


\section{ENVIRONMENTAL INDICATORS}

The environmental element of sustainability is focused on the principles of eco-system accommodation in terms of total energy resources as well as self-restoration limit with due consideration of the limited availability and continuous loss of natural resources (Lami \& Mecca, 2021). The overuse and single line withdrawal of non-renewable as well as renewable resources beyond the recuperation period will ultimately result in the replenishment of resources (Ahmad et $a l ., 2019)$. The environmental indicators are the physical elements of sustainability and are generally referred to as the corporal measurements of longevity and are listed in Table 1 . The prime focus lies on the consumption and efficacy of materials, natural and alternative sources including energy, water, and biomass, in addition to generation and recycling of waste and emissions (Abotalib et al., 2021).

Table 1. Category, sub-category and indicators for Environmental Sustainability

\begin{tabular}{|c|c|c|c|}
\hline Category & Sub-category & Indicator & References \\
\hline \multirow{3}{*}{ Material } & Non-renewable materials & \multirow{7}{*}{ 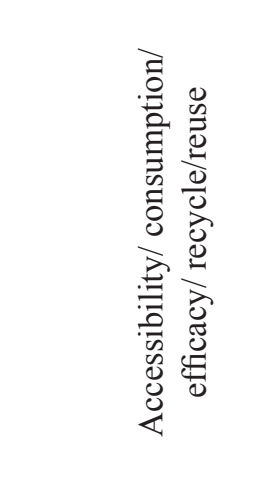 } & (Ghobadian et al., 2020) \\
\hline & Renewable materials & & (Sala, 2020) \\
\hline & Hazardous materials & & (Ahmad et al., 2019) \\
\hline \multirow{2}{*}{ Energy } & Non-Renewable energy & & (Akbar \& Irohara, 2018) \\
\hline & Renewable energy & & (Cobut et al., 2015) \\
\hline \multirow{2}{*}{ Water } & Input & & (Joung et al., 2013) \\
\hline & Output & & (Eastwood \& Haapala, 2015) \\
\hline \multirow{8}{*}{$\begin{array}{l}\text { Waste and } \\
\text { emissions }\end{array}$} & Primary air pollutant & \multirow{6}{*}{ 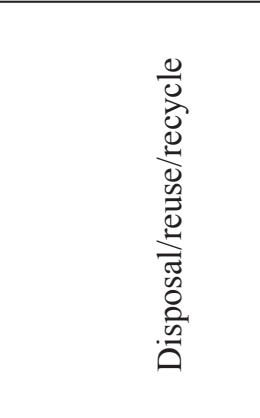 } & (Chaim et al., 2018) \\
\hline & Secondary air pollutant & & (Sala et al., 2016) \\
\hline & Solid waste & & (Talens Peiró et al., 2010) \\
\hline & Liquid effluents & & (Joung et al., 2013) \\
\hline & Climate gas emissions & & (Golinska et al., 2015) \\
\hline & Volatile organic compounds & & (Peralta Álvarez et al., 2017) \\
\hline & Noise pollution & Noise level & (Ahmad et al., 2019) \\
\hline & Heat generation & Amount & (Sala, 2020) \\
\hline \multirow{3}{*}{$\begin{array}{l}\text { Logistics and } \\
\text { reverse logistics }\end{array}$} & Packaging & \multirow{3}{*}{ Efficacy } & \multirow{3}{*}{ (Jin et al., 2017) } \\
\hline & Storage & & \\
\hline & Transportation & & \\
\hline \multirow{3}{*}{$\begin{array}{l}\text { Environmental } \\
\text { conformance }\end{array}$} & Certificates & Labels/reports & (Bracke et al., 2017) \\
\hline & Sanctions & Venture & (Moktadir et al., 2018) \\
\hline & Fines & Spending & (Platcheck et al., 2008) \\
\hline
\end{tabular}




\section{ECONOMIC INDICATORS}

Economic performance of any manufacturing unit is an important parameter that considers its economic success (Borchardt et al., 2011). The contribution that industry provides to the sustainable economic environment, in which it works, is less commonly reported but also desired by readers of sustainability studies (Singh et al., 2007). It is central to understanding the financial stability and the sustainable base of the unit and is generally reported in annual financial statements and statistics. However, the industry could be financially sustainable but may have been negatively influencing its stakeholders (Jawahir et al., 2013). Hence, economic indicators are designed to assess the economic impact of industrial operations and their influence on a wide variety of stakeholders (Table 2). These indicators also reflect the outcomes obtained in handling the overall financial resources, its success, and strategies required for performance improvement as listed in Table 2.

Table 2. Category, sub-category and indicators for Economic Sustainability

\begin{tabular}{|c|c|c|c|}
\hline Category & Sub-category & Indicator & References \\
\hline \multirow{9}{*}{ 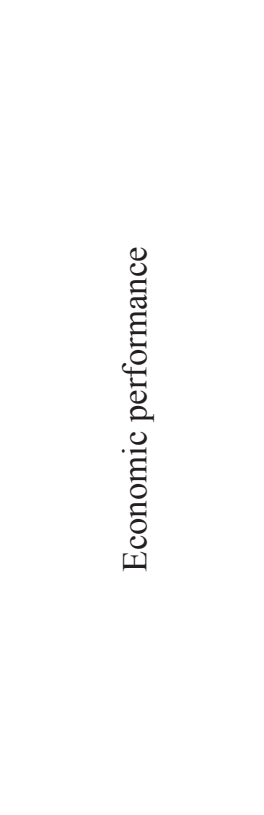 } & \multirow{2}{*}{$\begin{array}{c}\text { Directly generated economic } \\
\text { value }\end{array}$} & Revenue & (Bui et al., 2017) \\
\hline & & Financial assistance & (Sala, 2020) \\
\hline & \multirow{5}{*}{ Distributed economic value } & Operating cost & (Chong et al., 2018) \\
\hline & & Wages & (Boks, 2006) \\
\hline & & Debt payment & (Singh et al., 2009) \\
\hline & & Taxes & (Moktadir et al., 2018) \\
\hline & & Community investment & (Borchardt et al., 2011) \\
\hline & \multirow{2}{*}{ Retained economic value } & Investment & (Boulanger, 2008) \\
\hline & & Equity release & (Nikolova, 2013) \\
\hline \multirow{3}{*}{ Market viability } & \multirow{2}{*}{ Competitive wages } & Entry level distribution & (Boks, 2006) \\
\hline & & Senior level distribution & (Borchardt et al., 2011) \\
\hline & Viable practices & Local economy & (Boks, 2006) \\
\hline \multirow{3}{*}{ Economic impact } & Infrastructure & Community infrastructure & $\begin{array}{l}\text { (Badurdeen \& } \\
\text { Jawahir, 2017) }\end{array}$ \\
\hline & Direct impact & Financial transactions & (Moktadir et al., 2018) \\
\hline & Indirect impact & Socio-economic changes & $\begin{array}{l}\text { (Badurdeen \& } \\
\text { Jawahir, 2017) }\end{array}$ \\
\hline
\end{tabular}




\section{SOCIAL INDICATORS}

The impact of various manufacturing processes and products on society is measured through social indicators involving various aspects with due consideration of safety and health of employees and customers along with any negative impact on the nearby community (Chaim et al., 2018). Sustainable manufacturing requires the development and propagation of a vision of a socially sustainable workplace, with a safe, empowered, informed, and a willing workforce of all ages, gender, abilities, and stages of personal growth, to tackle the challenge of diminishing recruiting pool (Gebisa \& Lemu, 2017). The concept of equality, empowerment, inclusion, engagement, sharing, cultural identity, and institutional cohesion is the foundation of the social dimension of sustainability (Henao et al., 2017). It emphasizes society's solidarity and its ability to work towards shared objectives while addressing individual needs, such as health and well-being, nutrition, housing, education and cultural expression (Holm, 2018). These proactive visions will be vital to the potential growth of the industries, not only to ensure demographic continuity and employee fulfillment requirements but also to promote work-life balance and making efforts to promote welfare and development of all stakeholders. It also relies on improving customer satisfaction and community relations through feedback mechanism. The various categories and sub-categories for these indicators have been listed in Table 3 .

Table 3 Category, sub-category and indicators for Social Sustainability

\begin{tabular}{|c|c|c|c|}
\hline Category & Sub-category & Indicator & References \\
\hline \multirow{18}{*}{ 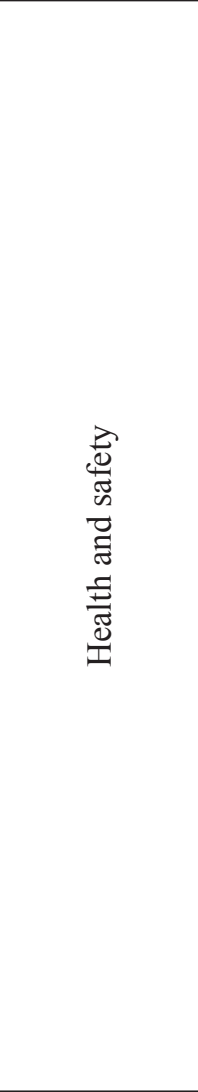 } & \multirow{11}{*}{ Employee } & Job availability and security & (Chaim et al., 2018) \\
\hline & & Employee turnover rate & (Chaim et al., 2018) \\
\hline & & Employee performance & (Holm, 2018) \\
\hline & & Legal benefits & (Lami \& Mecca, 2021) \\
\hline & & Equality policy & (Cor et al., 2014) \\
\hline & & Training and development & (Holm, 2018) \\
\hline & & Occupational health management & (Moreira et al., 2018) \\
\hline & & Career advancement & (Gebisa \& Lemu, 2017) \\
\hline & & Risk prevention and management & (Badurdeen \& Jawahir, 2017) \\
\hline & & Protective equipment & (Cor et al., 2014) \\
\hline & & Absentee's rate & (Bracke et al., 2017) \\
\hline & \multirow{4}{*}{ Customer } & Product information & (Badurdeen \& Jawahir, 2017) \\
\hline & & Customer satisfaction & (Borchardt et al., 2011) \\
\hline & & Product quality & (Chaim et al., 2018) \\
\hline & & Public trust & (Gebisa \& Lemu, 2017) \\
\hline & \multirow{3}{*}{ Community } & Demographic aspect & (Holm, 2018) \\
\hline & & Technology development & (Chaim et al., 2018) \\
\hline & & Human rights protection & (Bracke et al., 2017) \\
\hline \multirow{3}{*}{$\begin{array}{l}\text { Stakeholder } \\
\text { Engagement }\end{array}$} & Employee & Employee feedback & (Cor et al., 2014) \\
\hline & Customer & Customer feedback & (Gebisa \& Lemu, 2017) \\
\hline & Community & Community feedback & (Chaim et al., 2018) \\
\hline
\end{tabular}




\section{FUTURE GOALS FOR IMPLEMENTATION OF SUSTAINABLE MANUFACTURING METRICS}

The manufacturing sustainability assessment requires a uniform and systematic inclusion of various aspects of sustainability metrics (Stevanovic, 2018). In order to improve the results and to fill the void, a standardized course plan should be implemented based upon the consensus of manufacturers, stakeholders, and policy-makers (Sala, 2020). Since, all indicators might not be equally relevant in all industries, more efficient metrics should be developed so as to define priorities and measure indicator weights in varying sectors. The route for sustainability can be achieved step by step by completing seven phases as shown in Figure 3.

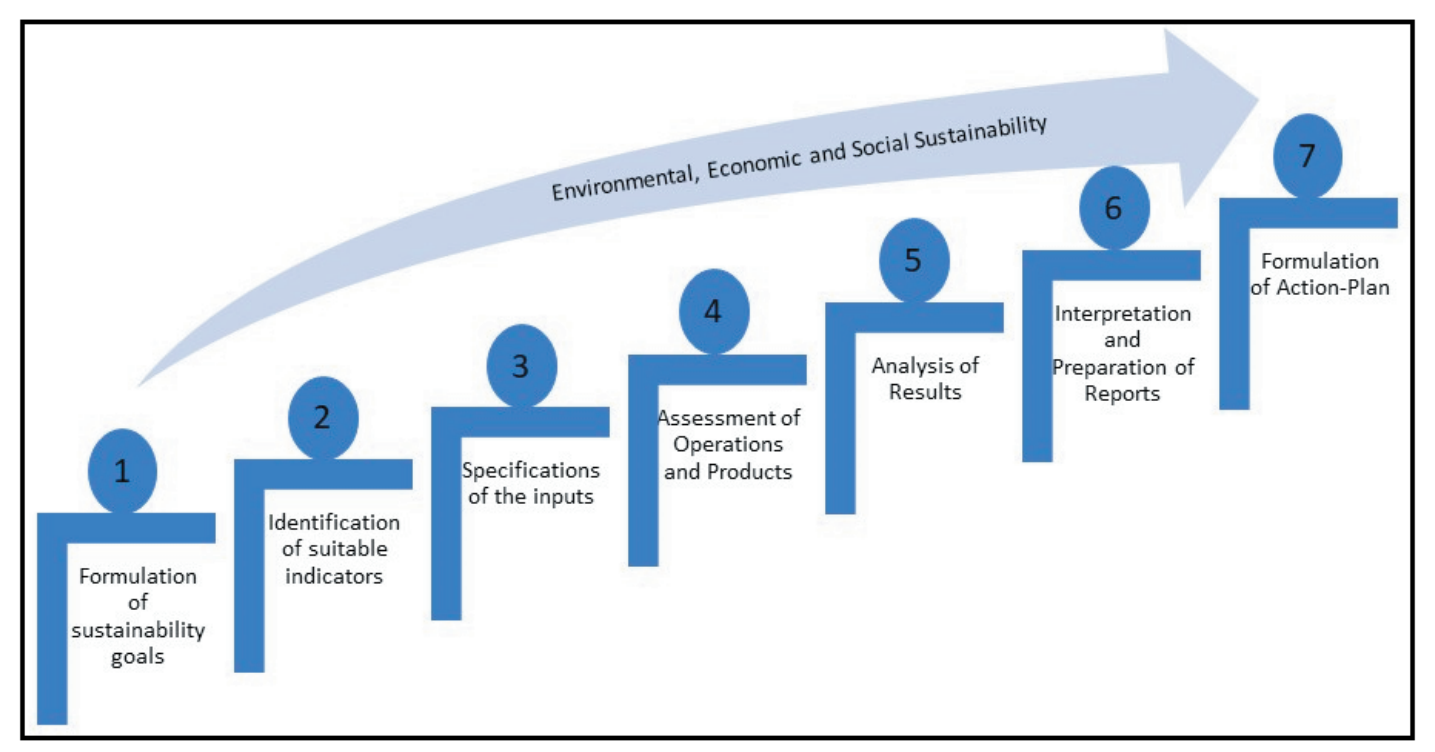

Figure 3. Route for Sustainability

The journey begins with formulating the sustainability goals as an addressal to various issues due to the environmental, economic, and social impacts of the manufacturing units through the involvement of management and stakeholders (Libório et al., 2020). Depending upon the priorities, suitable indicators must be identified from the indicator repository that can suitably analyze the impact of various manufacturing operations and products through its complete life cycle. Various inputs like materials and energy resources used at all process levels must be specified and their impact on the environment, economy, and society must be identified (Taddese et al., 2020). The efficacy and impact of all manufacturing operations on the environment, economy, and society must be assessed. The life cycle evaluation of the product must be carried out to determine its sustainability. The proper documentation of results must be carried out that can provide the contextual interpretation and indicate the performance trends of the manufacturing unit (Lami \& Mecca, 2021). As per the final report, a necessary action-pan must be formulated for improved efficacy of the economy, environmental conformance, and healthy society in a steady and progressive manner by assigning new benchmarks and considering alternative options at each step (Rai et al., 2021).

\section{CONCLUSION}

This paper addresses the basics, methods of implementation, and assessment tools for sustainable manufacturing using suitable sustainability indicators. The review and evaluation of various reports reveal that the three main sustainability assessment indicators don't carry equal weightage and less stress is laid on social indicators. Further, all 
indicators are not used equally by various industries. In the case of environmental indicators, generally, more stress is laid on gaseous emission as compared to solid and liquid waste, possibly due to global consideration of air pollutants. However, industrial effluent is a prime matter of concern for food processing industries. Likewise, in the case of economic indicators, more frequency has been observed for revenue, investment, and operating cost as compared to taxes, wages distribution, and local economy. While, in the case of social indicators, more stress is laid on job availability as compared to equity policy and feedback. It is clear from this analysis that there are many deficiencies in measuring and managing sustainability in manufacturing units related to the sustainability market positioning. Hence, inclusion of all critical indicators can help manufacturers, customers, and policy-makers to address the environmental, economic, and social issues and lead towards sustainability in a steady manner.

\section{REFERENCES}

Abotalib, M., Jacob, J., Alhamadi, H., \& Alkandari, D. 2021. The environmental life cycle assessment of different electricity options in Kuwait. Journal of Engineering Research, 9: 308-319.

Abualfaraa, W., Salonitis, K., Al-Ashaab, A., \& Ala'raj, M. 2020. Lean-Green Manufacturing Practices and Their Link with Sustainability: A Critical Review. Sustainability, 12: 981.

Ahmad, S., Wong, K. Y., \& Rajoo, S. 2019. Sustainability indicators for manufacturing sectors. Journal of Manufacturing Technology Management, 30: 312-334.

Ahmad, S., Wong, K. Y., Tseng, M. L., \& Wong, W. P. 2018. Sustainable product design and development: A review of tools, applications and research prospects. Resources, Conservation and Recycling, 132: 49-61.

Akbar, M., \& Irohara, T. 2018. Scheduling for sustainable manufacturing: A review. Journal of Cleaner Production, 205: 866-883.

Badurdeen, F., \& Jawahir, I. S. 2017. Strategies for Value Creation Through Sustainable Manufacturing. Procedia Manufacturing, 8: 20-27.

Beng, L. G., \& Omar, B. 2014. Integrating axiomatic design principles into sustainable product development. International Journal of Precision Engineering and Manufacturing-Green Technology, 1: 107-117.

Boks, C. 2006. The soft side of ecodesign. Journal of Cleaner Production, 14: 1346-1356.

Borchardt, M., Wendt, M. H., Pereira, G. M., \& Sellitto, M. A. 2011. Redesign of a component based on ecodesign practices: environmental impact and cost reduction achievements. Journal of Cleaner Production, 19: 49-57.

Boulanger, P.-M. 2008. Sustainable development indicators: a scientific challenge, a democratic issue. Surveys and Perspectives Integrating Environment and Society, 1: 59-73.

Bracke, S., Yamada, S., Kinoshita, Y., Inoue, M., \& Yamada, T. 2017. Decision Making within the Conceptual Design Phase of Eco-Friendly Products. Procedia Manufacturing, 8: 463-470.

Bui, N. T., Kawamura, A., Kim, K. W., Prathumratana, L., Kim, T.-H., Yoon, S.-H., Jang, M., Amaguchi, H., Bui, D. Du, \& Truong, N. T. 2017. Proposal of an indicator-based sustainability assessment framework for the mining sector of APEC economies. Resources Policy, 52: 405-417.

Chaim, O., Muschard, B., Cazarini, E., \& Rozenfeld, H. 2018. Insertion of sustainability performance indicators in an industry 4.0 virtual learning environment. Procedia Manufacturing, 21: 446-453.

Chong, L., Ramakrishna, S., \& Singh, S. 2018. A review of digital manufacturing-based hybrid additive manufacturing processes. The International Journal of Advanced Manufacturing Technology, 95: 2281-2300.

Cobut, A., Beauregard, R., \& Blanchet, P. 2015. Reducing the environmental footprint of interior wood doors in non-residential buildings - part 2: ecodesign. Journal of Cleaner Production, 109: 247-259. 
Cor, E., Domingo, L., Brissaud, D., \& Zwolinski, P. 2014. A protocol to perform usage oriented ecodesign. CIRP Annals, 63: 169-172.

Eastwood, M. D., \& Haapala, K. R. 2015. A unit process model based methodology to assist product sustainability assessment during design for manufacturing. Journal of Cleaner Production, 108: 54-64.

Garza-Reyes, J. A. 2015. Green lean and the need for Six Sigma. International Journal of Lean Six Sigma, 6: 226-248.

Gebisa, A. W., \& Lemu, H. G. 2017. Design for manufacturing to design for Additive Manufacturing: Analysis of implications for design optimality and product sustainability. Procedia Manufacturing, 13: 724-731.

Ghobadian, A., Talavera, I., Bhattacharya, A., Kumar, V., Garza-Reyes, J. A., \& O'Regan, N. 2020. Examining legitimatisation of additive manufacturing in the interplay between innovation, lean manufacturing and sustainability. International Journal of Production Economics, 219: 457-468.

Golinska, P., Kosacka, M., Mierzwiak, R., \& Werner-Lewandowska, K. 2015. Grey Decision Making as a tool for the classification of the sustainability level of remanufacturing companies. Journal of Cleaner Production, 105: 28-40.

Henao, R., Sarache, W., \& Gomez, I. 2017. Social Performance Metrics for Manufacturing Industry. 24th EurOMA Conference, July, 1-10.

Holm, M. 2018. The future shop-floor operators, demands, requirements and interpretations. Journal of Manufacturing Systems, 47: 35-42.

Huang, A., \& Badurdeen, F. 2017. Sustainable Manufacturing Performance Evaluation: Integrating Product and Process Metrics for Systems Level Assessment. Procedia Manufacturing, 8: 563-570.

Jawahir, I. S., Badurdeen, F., \& Rouch, K. E. 2013. Innovation in Sustainable Manufacturing Education. In Proceedings of the 11th Global Conference on Sustainable Manufacturing - Innovative Solutions.

Jawahir, I. S., Wanigarathne, P. C., \& Wang, X. 2015. Product Design and Manufacturing Processes for Sustainability. In Mechanical Engineers 'Handbook (pp. 1-29). John Wiley \& Sons, Inc.

Jin, M., Tang, R., Ji, Y., Liu, F., Gao, L., \& Huisingh, D. 2017. Impact of advanced manufacturing on sustainability: An overview of the special volume on advanced manufacturing for sustainability and low fossil carbon emissions. Journal of Cleaner Production, 161: 69-74.

Joung, C. B., Carrell, J., Sarkar, P., \& Feng, S. C. 2013. Categorization of indicators for sustainable manufacturing. Ecological Indicators, 24: 148-157.

Jung, J., Jeong, I., Lee, K. J., Won, G., \& Park, J. B. 2018. Effects of changes in occupational stress on the depressive symptoms of Korean workers in a large company: A longitudinal survey. Annals of Occupational and Environmental Medicine, 30: 1-12.

Lami, I. M., \& Mecca, B. 2021. Assessing social sustainability for achieving sustainable architecture. Sustainability (Switzerland), 13: 1-21.

Libório, M. P., Martinuci, O. da S., Laudares, S., Lyrio, R. de M., Machado, A. M. C., Bernardes, P., \& Ekel, P. 2020. Measuring intra-urban inequality with structural equation modeling: A theory-grounded indicator. Sustainability (Switzerland), 12: 1-18.

Moktadir, M. A., Rahman, T., Rahman, M. H., Ali, S. M., \& Paul, S. K. 2018. Drivers to sustainable manufacturing practices and circular economy: A perspective of leather industries in Bangladesh. Journal of Cleaner Production, 174: $1366-1380$.

Moreira, S., Vasconcelos, L., \& Silva Santos, C. 2018. Occupational health indicators: Exploring the social and decent work dimensions of green jobs in Portugal. Work, 61: 189-209. 
Murakami, S., Takasu, T., Islam, K., Yamasue, E., \& Adachi, T. 2020. Ecological footprint and total material requirement as environmental indicators of mining activities: Case studies of copper mines. Environmental and Sustainability Indicators, 8: 100082.

Nikolova, V. 2013. Multi-stakeholder Approach in Corporate Social Responsibility. Encyclopedia of Corporate Social Responsibility, 3: 1731-1731.

Peralta Álvarez, M. E., Marcos Bárcena, M., \& Aguayo González, F. 2017. On the sustainability of machining processes. Proposal for a unified framework through the triple bottom-line from an understanding review. Journal of Cleaner Production, 142: 3890-3904.

Pereira, T., Kennedy, J. V., \& Potgieter, J. 2019. A comparison of traditional manufacturing vs additive manufacturing, the best method for the job. Procedia Manufacturing, 30: 11-18.

Pinto, L. F. R., Venturini, G. de F. P., Digiesi, S., Facchini, F., \& Oliveira Neto, G. C. de. 2020. Sustainability Assessment in Manufacturing under a Strong Sustainability Perspective-An Ecological Neutrality Initiative. Sustainability, 12: 9232.

Platcheck, E. R., Schaeffer, L., Kindlein, W., \& Cãndido, L. H. A. 2008. Methodology of ecodesign for the development of more sustainable electro-electronic equipments. Journal of Cleaner Production, 16: 75-86.

Rai, S. S., Rai, S., \& Singh, N. K. 2021. Organizational resilience and social-economic sustainability: COVID-19 perspective. Environment, Development and Sustainability, 0123456789.

Rosen, M. A., \& Kishawy, H. A. 2012. Sustainable Manufacturing and Design: Concepts, Practices and Needs. Sustainability, 4: 154-174.

Sala, S. 2020. Triple bottom line, sustainability and sustainability assessment, an overview. In Biofuels for a More Sustainable Future (pp. 47-72). Elsevier.

Sala, S., Reale, F., Cristóbal-García, J., Marelli, L., \& Rana, P. 2016. Life cycle assessment for the impact assessment of policies. Life thinking and assessment in the European policies and for evaluating policy options. In Publications Office of the European Union (Vol. 28380, Issue December).

Singh, R. K., Murty, H. R., Gupta, S. K., \& Dikshit, A. K. 2007. Development of composite sustainability performance index for steel industry. Ecological Indicators, 7: 565-588.

Singh, R. K., Murty, H. R., Gupta, S. K., \& Dikshit, A. K. 2009. An overview of sustainability assessment methodologies. Ecological Indicators, 9: 189-212.

Stevanovic, S. 2018. Urban planning indicators in sustainable building assessment methods. Journal of Engineering Research, 5: 1-14.

Sudusinghe, J. I., \& Seuring, S. 2020. Social sustainability empowering the economic sustainability in the global apparel supply chain. Sustainability (Switzerland), 12: 1-18.

Taddese, G., Durieux, S., \& Duc, E. 2020. Sustainability performance indicators for additive manufacturing: a literature review based on product life cycle studies. The International Journal of Advanced Manufacturing Technology, 107: 3109-3134.

Talens Peiró, L., Lombardi, L., Villalba Méndez, G., \& Gabarrell i Durany, X. 2010. Life cycle assessment (LCA) and exergetic life cycle assessment (ELCA) of the production of biodiesel from used cooking oil (UCO). Energy, 35: 889-893.

Wu, Y., \& Su, D. 2020. Social Life Cycle Assessment. In Sustainable Product Development (pp. 127-152). Springer International Publishing.

Zhou, G., Hu, W., \& Huang, W. 2016. Are Consumers Willing to Pay More for Sustainable Products? A Study of Eco-Labeled Tuna Steak. Sustainability, 8: 494. 